THE objectives of this work are to investigate the incorporation of arachidonic acid (AA) in the human myeloma cell lines OPM2, U266 and IM9, and to assess the effect of $\mathrm{AA}$ and lipoxygenase products of $\mathrm{AA}$ on their growth. The kinetics of acylation of $\left[{ }^{3} \mathrm{H}\right] \mathrm{AA}$ indicates that myeloma cells incorporate $\mathrm{AA}$ into their membrane phospholipids and triglycerides. PLA $_{2}$-treatment and base hydrolysis experiments confirm that $\left[{ }^{3} \mathrm{H}\right] \mathrm{AA}$ is incorporated unmodified in $\mathrm{U} 266$, IM9 and OPM2 phospholipids, and is linked by an ester bond. Prelabeling-chase experiments indicate no trafficking of labeled $A A$ among the various phospholipid species. Addition of AA and lipoxygenase products of $A A$ (leukotriene $B_{4}$ and $C_{4}$, lipoxin $A_{4}$ and $B_{4}, 12$ - and 15-hydroxyeicosatetraenoic acid) have no effect on U266, IM9 and OPM2 proliferation assessed by $\left.{ }^{3} \mathbf{H}\right]$ thymidine incorporation into DNA. In conclusion, while human myeloma cells readily incorporate $A A$ in their membrane phospholipids and triglycerides, AA and lipoxygenase products are not important modulators of their proliferation.

Key words: Arachidonic acid, Myeloma cells, Lipoxygenase metabolites, Proliferation

\section{Incorporation and effect of arachidonic acid on the growth of human myeloma cell lines}

\author{
V. Desplat, C. Dulery, V. Praloran and Y. Denizot ${ }^{\mathrm{CA}}$
}

Laboratoire d'Hématologie Expérimentale, Faculté de Médecine, 2 rue Dr. Marcland, 87025 Limoges, France

${ }^{\mathrm{CA}}$ Corresponding Author

Fax: (+33) 555435866

\section{Introduction}

The lipoxygenase pathway converts arachidonic acid (AA), a 20-carbon polyunsaturated fatty acid, in hydroxyeicosatetraenoic acid (HETE), lipoxins (LX) and leukotrienes (LT). ${ }^{1}$ Lipoxygenase inhibitors enhance the proliferation of human B cells in vitro, ${ }^{2}$ while they have antiproliferative effects on malignant hematopoietic cell lines, ${ }^{3,4}$ thus suggesting a role of endogenous lipoxygenase metabolites of AA during cell proliferation. While exogenous lipoxygenase products modulate cell proliferation in several cell types, ${ }^{5-7}$ their effect (if any) on the growth of human $B$ cell lines are not documented. In this study we have investigated the incorporation of AA in three human myeloma cell lines (i.e. IM9, U266 and OPM2) and the effect of AA and lipoxygenase metabolites, such as $\mathrm{LTB}_{4}, \mathrm{LTC}_{4}, \mathrm{LXA}_{4}, \mathrm{LXB}_{4}, 12$-HETE and 15-HETE, on their proliferation.

\section{Materials and Methods}

Incorporation of $\left[{ }^{3} \mathrm{H}\right] \mathrm{AA}$ in myeloma cells

U266, IM9 and OPM2 were obtained from the American Type Culture Collection (Rockville, MD). Cells were grown in suspension in RPMI 1640 supplemented with $10 \%$ fetal calf serum (FCS) (Gibco, Cergy Pontoise, France), penicillin (100 U/ml) and streptomycin $(100 \mathrm{mg} / \mathrm{ml})$ at $37^{\circ} \mathrm{C}$ in $5 \% \mathrm{CO}_{2}$ in air. Before use, cells were washed twice in Hanks' balanced salts solution (HBSS) and numerated. The incorporation of $\left[{ }^{3} \mathrm{H}\right] \mathrm{AA}$ (Amersham, Les Ulis, France) was performed with cells $\left(3 \times 10^{6}\right)$ in $1 \mathrm{ml}$ of RPMI 1640 medium without FCS. $\left[{ }^{3} \mathrm{H}\right] \mathrm{AA}(0.1 \mu \mathrm{Ci} ; 210 \mathrm{Ci} /$ mmol) was added into the medium for various periods of time. At the end of the experiments, cells were harvested by centrifugation $(800 \times \mathrm{g}, 10 \mathrm{~min})$ and then stored at $-20^{\circ} \mathrm{C}$ until use. For AA remodeling studies, cells were labeled with $\left[{ }^{3} \mathrm{H}\right] \mathrm{AA}$ for $30 \mathrm{~min}$, washed with HBSS, and incubated in $1 \mathrm{ml}$ of RPMI 1640 without FCS for $7 \mathrm{~h}$ or used immediately. For these experiments cells were stored as above.

\section{Lipid extraction}

Cells were mixed with $1 \mathrm{ml}$ of $0.1 \%$ sodium dodecyl sulfate in water, and incubated for $30 \mathrm{~min}$ at $56^{\circ} \mathrm{C}$ with $3 \mathrm{ml}$ of chloroform/methanol $(2: 1, \mathrm{v} / \mathrm{v})$. The chloroformic extract was washed with $5 \mathrm{ml}$ of $0.1 \mathrm{M} \mathrm{KCl} /$ methanol/chloroform (96:92:6, v/v/v), and was evaporated. ${ }^{8}$ The dry extract was recovered in $150 \mu 1$ of chloroform and applied to a thin-layer chromatography (TLC) plate (Silica gel $60(20 \times 20 \mathrm{~cm}, 0.25 \mathrm{~mm})$, Merck) and submitted toTLC. The plate was developed in the mixture of diethyl ether/hexane/acetic acid $(70: 30: 1, \mathrm{v} / \mathrm{v} / \mathrm{v}) .{ }^{9}$ Each lane was divided into areas of $0.5 \mathrm{~cm}$ in length which were scraped into vials, and radioactivity was measured on a Packard liquid scintillation counter. Solutions of monoglycerides 
(MG), diglycerides (DG), triglycerides (TG), phospholipids (PL) and AA (Sigma, Saint Quentin Fallavier, France) were used as standards and visualized with iodine vapor.

\section{Analysis of labeled PL}

For the separation of the various species of cellular PL, the corresponding areas were scraped from the TLC plates and were extracted with chloroform/ methanol $(2: 1, v / v)$. Samples were then rechromatographed using a solvent system of chloroform/ methanol/acetic acid/water (50:30:8:4, v/v/v/v). ${ }^{8}$ Each lane was divided into areas of $0.5 \mathrm{~cm}$ in length and processed as above. Solutions of phosphatidylethanolamine (PE), phosphatidylcholine (PC), phosphatidylserine (PS) and phosphatidylinositol (PI) (Sigma) were used as standards and visualized with iodine vapor. In this chromatography, PI and PS migrated to the same area.

Base hydrolysis and PLA2 treatment of labeled $\mathrm{PL}$

In a first set of experiments, the labeled PL were resuspended in $1 \mathrm{ml}$ of $2 \mathrm{M} \mathrm{KOH}$ in ethanol/water $(3: 1, \mathrm{v} / \mathrm{v})$ as previously reported. ${ }^{9}$ After $40 \mathrm{~min}$ at $60^{\circ} \mathrm{C}, 1 \mathrm{ml}$ of water and $1 \mathrm{ml}$ of $6 \mathrm{~N} \mathrm{HCl}$ were added to the mixture to acidify the phase ( $\mathrm{pH} 3$ ). Labeled compounds were extracted with chloroform/methanol $(2: 1, \mathrm{v} / \mathrm{v})$ and rechromatographed using a solvent system of diethyl ether/hexane/acetic acid (70:30:1, v/v/v). The amount of radioactivity migrating with PL and free AA was determined by liquid scintillation counting. In another set of experiments, labeled PL were hydrolysed with $\mathrm{PLA}_{2}$ from bovine pancreas (Sigma). Briefly, labeled PL samples were resuspended in $1 \mathrm{ml}$ of diethyl ether/methanol $(95: 5, \mathrm{v} / \mathrm{v})$ containing $50 \mu \mathrm{l}$ of Tris buffer $(0.05 \mathrm{M}), \mathrm{CaCl}_{2}$ $(25 \mathrm{mM})$, EDTA $(1 \mathrm{mM})$, and $1 \mathrm{mg}$ of phospholipase. The reaction mixture was incubated at $37^{\circ} \mathrm{C}$ for $2 \mathrm{~h}$ with continuous shaking. After evaporation of solvent, samples were rechromatographed as for base hydrolysis.

\section{Proliferation studies}

U266, IM9 and OPM2 cells $\left(5 \times 10^{5}\right.$ per well) were cultured in 96-well microtiter plates in $100 \mu 1$ of RPMI 1640 with $10 \%$ FCS in the presence of AA, $\mathrm{LTB}_{4}, \mathrm{LTC}_{4}$, $\mathrm{LXA}_{4}, \mathrm{LXB}_{4}, 12$-HETE and 15-HETE $(1 \mu \mathrm{M})$ or the appropriate vehicle $(10 \mu 1$ of $2 \%$ human serum albumin). ${ }^{10}$ After $64 \mathrm{~h}$ of incubation, cultures were pulsed for $8 \mathrm{~h}$ with $1 \mu \mathrm{Ci} / \mathrm{ml}$ of $\left[{ }^{3} \mathrm{H}\right]$ thymidine and cells were harvested using a Skatron cell harvester. Each experiment was carried out on $n=6$ samples. Data were compared by Mann-Whitney $U$-test. A $P<0.05$ was considered significant.

\section{Results and Discussion}

As reported in Fig. 1, OPM2, U266 and IM9 incorporate $\left[{ }^{3} \mathrm{H}\right] \mathrm{AA}$ into their membrane lipids. The distribution of label in cell lipids as a function of time indicates that the majority of label is found with TG

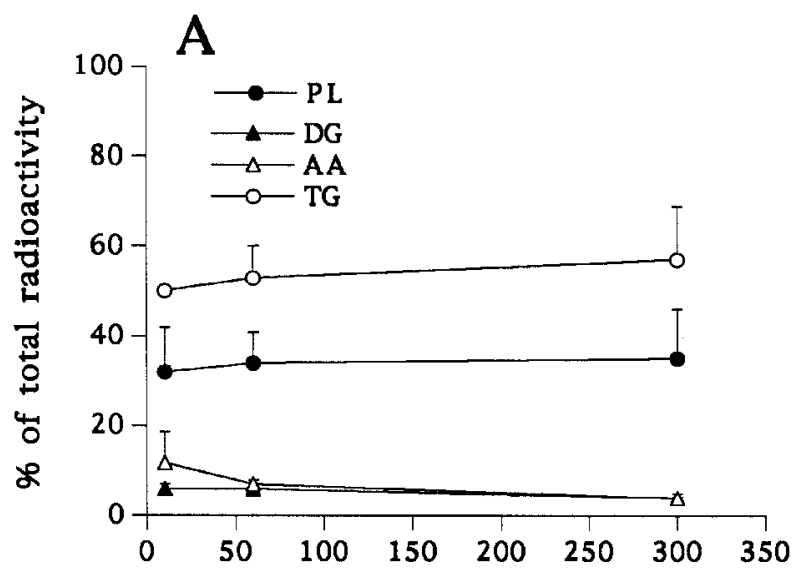

Time (min)
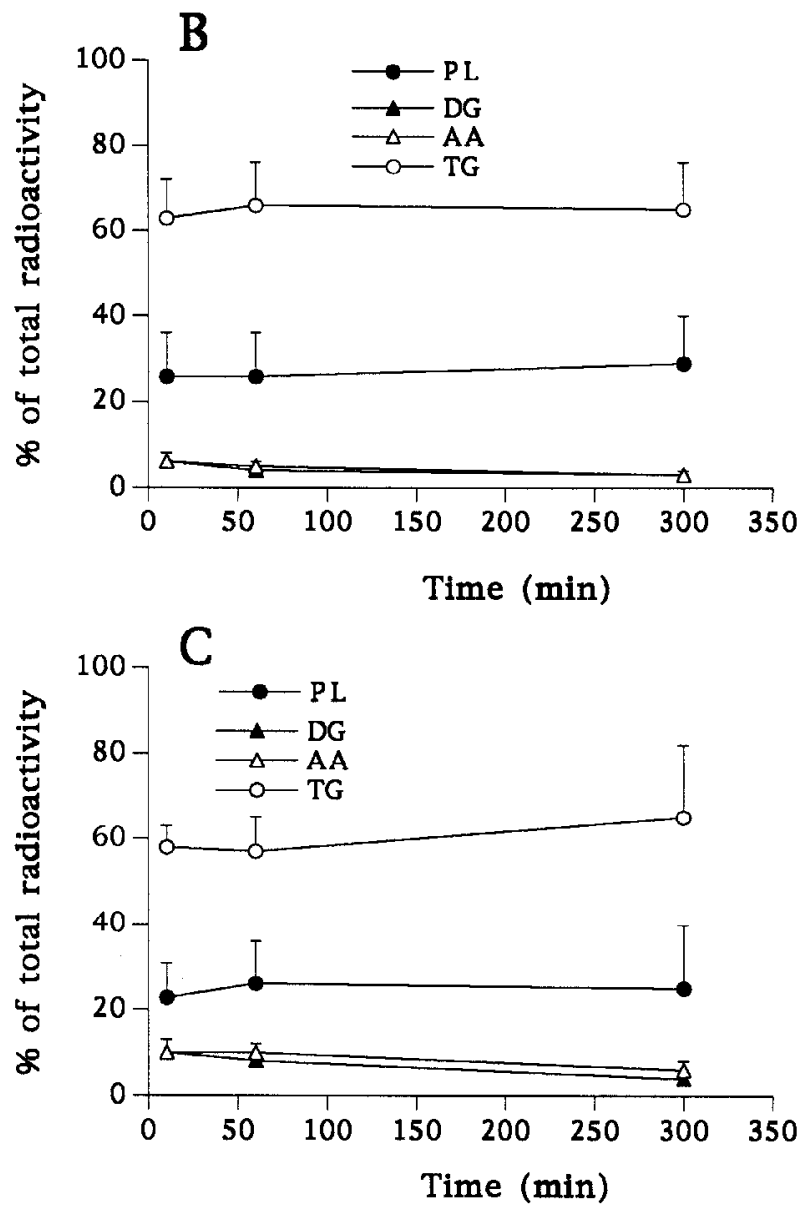

FIG. 1. Time-course of $\left[{ }^{3} \mathrm{H}\right] A A$ incorporation into U266 (A), OPM2 (B) and IM9 (C) cell lipids. Cells $\left(3 \times 10^{6}\right)$ were incubated with [ $\left.{ }^{3} \mathrm{H}\right] \mathrm{AA}$ for 10,60 and $300 \mathrm{~min}$. Cell lipids were extracted and separated as described in Materials and Methods. Results are expressed as the percentage of total radioactivity found in cells: mean $\pm S$.E.M. of three independent experiments in duplicate. PL, phospholipids; DG, diglycerides; TG, triglycerides; AA, arachidonic acid. 
and PL. Less than 10\% of label is recovered in DG or as free AA, and labeled MG are not detected.A transfer of AA from TG to PL has been reported in several human cell types. ${ }^{11}$ This trafficking is not found in U266, IM9 and OPM2 cells. Authors have suggested that the incorporation of $\left[{ }^{3} \mathrm{H}\right] \mathrm{AA}$ into the different cellular lipid species does not exactly reflect the distribution of the arachidonate mass in them, since the exogenous $\left[{ }^{3} \mathrm{H}\right] \mathrm{AA}$ might be incorporated into the less abundant AA-containing lipid species. ${ }^{12}$ In our experimental conditions the addition of unlabeled AA $(0.1 \mu \mathrm{M})$ into culture medium has no significant effect on the incorporation and distribution of $\left[{ }^{3} \mathrm{H}\right] \mathrm{AA}$ in $\mathrm{PL}$ and TG of U266, IM9 and OPM2 cells (data not shown). Finally the base hydrolysis of labeled PL from myeloma cells results in the loss of 98\% (mean of three experiments) of radioactivity, which was recovered as free fatty acid. Similarly, treatment of labeled PL with PLA 2 from bovine pancreas leads to the loss of $90 \%$ (mean of three experiments) of label. Thus, base hydrolysis and PLA 2 -treatment experiments indicate that $\left[{ }^{3} \mathrm{H}\right] \mathrm{AA}$ is incorporated unmodified in myeloma cell PL and is linked by an ester bond.

The distribution of $\left[{ }^{3} \mathrm{H}\right] \mathrm{AA}$ into $\mathrm{PL}$ species using myeloma cells labeled for $30 \mathrm{~min}$ is reported in Table 1. PC and PE are the major PL species in OPM2, IM9 and U266 cells. Prelabeling-chase experiments have documented a trafficking of labeled AA from PC to PE in several inflammatory cell types. ${ }^{13}$ To investigate the putative exchange of labeled AA between PL species, myeloma cells labeled for $30 \mathrm{~min}$ were washed and grown in culture medium free of $\left[{ }^{3} \mathrm{H}\right] \mathrm{AA}$ for $7 \mathrm{~h}$. Under these experimental conditions no trafficking of $\left[{ }^{3} \mathrm{H}\right] \mathrm{AA}$ from PC to PE is documented for OPM2, U266 and IM9 cells (data not shown). Studies report that lipoxygenase and cyclooxygenase products of AA might derive from different $\mathrm{PL}$ species in some inflammatory cell types. ${ }^{12}$ Thus, two sources of AA are released during immunological activation of mast cells. ${ }^{14}$ PC provides AA for LTs biosynthesis, while PE provides the released AA that might be used for the production of cyclooxygenase products. Clearly the role of the different PL species on the production of lipoxygenase and cyclooxygenase metabolites of AA by human myeloma cells deserve to be investigated.

Table 1. Incorporation of $\left[{ }^{3} \mathrm{H}\right] \mathrm{AA}$ into $\mathrm{PL}$ species of OPM2, U266 and IM9 cells

\begin{tabular}{lccc}
\hline & PC (\%) & PI + PS (\%) & PE (\%) \\
\hline OPM2 & $59 \pm 3$ & $17 \pm 1$ & $24 \pm 4$ \\
IM9 & $35 \pm 3$ & $27 \pm 1$ & $38 \pm 5$ \\
U266 & $53 \pm 5$ & $18 \pm 1$ & $29 \pm 5$ \\
\hline
\end{tabular}

Cells $\left(3 \times 10^{6}\right)$ were labeled for $0.5 \mathrm{~h}$ with $\left[{ }^{3} \mathrm{H}\right] \mathrm{AA}$. Results are expressed as the percentage of total radioactivity found in PL species: mean \pm S.E.M. of three independent experiments in duplicate. PC phosphatidylcholine; $\mathrm{PE}$, phosphatidylethanolamine; PI+PS, phosphatidylinositol+phosphatidylserine (comigration).
Table 2. Effects of $A A$ and lipoxygenase metabolites on $\left[{ }^{3} \mathrm{H}\right]$ thymidine incorporation of U266, OPM2 and IM9 cells

\begin{tabular}{lcll}
\hline & U266 & \multicolumn{1}{c}{ OPM2 } & \multicolumn{1}{c}{ IM9 } \\
\hline Controls & $16492 \pm 1984$ & $288474 \pm 40225$ & $5784 \pm 510$ \\
AA & $13897 \pm 1111$ & $268889 \pm 29266$ & $5627 \pm 822$ \\
LTB $_{4}$ & $15836 \pm 1731$ & $264995 \pm 26473$ & $6052 \pm 1048$ \\
LTC $_{4}$ & $15726 \pm 2671$ & $262626 \pm 27123$ & $5194 \pm 956$ \\
LXA $_{4}$ & $15042 \pm 1300$ & $266017 \pm 27033$ & $6212 \pm 820$ \\
LXB $_{4}$ & $12610 \pm 3135$ & $259149 \pm 10066$ & $5688 \pm 1367$ \\
12-HETE & $13333 \pm 2491$ & $292534 \pm 29602$ & $5069 \pm 925$ \\
15-HETE & $14730 \pm 2491$ & $279571 \pm 29602$ & $6315 \pm 940$ \\
\hline
\end{tabular}

Cells $\left(5 \times 10^{5}\right)$ were grown for 3 days in $10 \%$ FCS in the presence or absence of $1 \mu \mathrm{M}$ of $\mathrm{AA}, \mathrm{LTB}_{4}, \mathrm{LTC}_{4}, \mathrm{LXA}_{4}, \mathrm{LXB}_{4}, 12-\mathrm{HETE}$ and 15-HETE. Results (in $\mathrm{dpm}$ ) are the mean \pm S.E.M. from four independent experiments in $n=6$ samples.

The addition of lipoxygenase metabolite of AA is reported to modulate the growth of various cell types. ${ }^{5-7}$ We then assessed their putative role on the proliferation of human myeloma cells. As reported in Table 2, the addition of micromolar amounts of AA, $\mathrm{LTB}_{4}, \mathrm{LTC}_{4}, \mathrm{LXA}_{4}, \mathrm{LXB}_{4}, 12$-HETE and 15-HETE has no significant $(P>0.05$, Mann-Whitney $U$-test, four independent experiments) effect on the $\left[{ }^{3} \mathrm{H}\right]$ thymidine incorporation of U266, IM9 and OPM2 cells. This result is in accord with the fact that the enhanced B-cell proliferation caused by lipoxygenase blockade could not be reversed by the exogenous addition of LTs or HETEs. ${ }^{2}$ In this study we have only investigated the effects of lipoxygenase products of AA on the growth of myeloma cells. However, cyclooxygenase products of AA such as prostaglandin $\mathrm{E}_{2}$ are reported to modulate the proliferation of several cell types. ${ }^{15,16}$ Clearly their role on the growth of U266, IM9 and OPM2 cells deserves to be clarified.

In conclusion, while human myeloma cells incorporate $\mathrm{AA}$ in their membrane phospholipids and triglycerides, exogenous AA and lipoxygenase products are not important modulators of their proliferation, a result that markedly differs to their reported endogenous role.

ACKNOWLEDGEMENTS. We are grateful to the "Ligue Nationale Contre le Cancer" (Comité de la Corrèze et de la Creuse) and to the "Conseil Régional du Limousin" for funding our project. V.D. is supported by a grant from the "Ligue Nationale Contre le Cancer" (Comité de la Corrèze)

\section{References}

1. Sigal E. The molecular biology of mammalian arachidonic acid metabolism. Am J Physiol 1991: 260: L13-28.

2. Behrens TW, Lum LG, Lianos EA, Goodwin JS. Lipoxygenase inhibitors enhance the proliferation of human B cells. J Immunol 1989: 143: 2285-2294.

3. Snyder DS, Castro R, Desforges JF Antiproliferative effects of lipoxygenase inhibitors on malignant human hematopoietic cell lines. Exp Hematol 1989: 17: 6-9.

4. Tsukada T, Nakashima K, Shirakawa S. Arachidonate 5-lipoxygenase inhibitors show potent antiproliferative effects on human leukemia cell lines. Biochim Biophys Acta 1986: 140: 832-836.

5. Setty BNY, Graeber JE, Stuart MJ. The mitogenic effect of 15- and 12-hydroxyeicosatetraenoic acid on endothelial cells may be mediated via diacylglycerol kinase inhibition. J Biol Chem 1987: 262: 17613-17622. 
6. Werner EJ, Walenga RW, Dubowy RL, Boone S, Stuart MJ. Inhibition of human malignant neuroblastoma cell DNA synthesis by lipoxygenase metabolites of arachidonic acid. Cancer Res 1985: 45: 561-563.

7. Ondrey F, Harris JE, Anderson KM. Inhibition of U937 eicosanoid and DNA synthesis by 5,8,11,14-eicosatetraynoic acid, an inhibitor of arachidonic acid metabolism, and its partial reversal by leukotriene $\mathrm{C} 4$. Cancer Res 1989: 49: 1138-1142.

8. Denizot Y, Desplat V, Dulery C, Trimoreau F, Praloran V. Arachidonic acid and freshly isolated human bone marrow mononuclear cells. Med Inflamm 1999: 8: 31-35.

9. Triggiani M, Oriente A, Marone G. Differential roles for triglyceride and phospholipid pools of arachidonic acid in human lung macrophages. $J$ Immunol 1994: 152: 1394-1403.

10. Desplat V, Dupuis F, Trimoreau F, Dulery C, Praloran V, Denizot Y. Effects of lipoxygenase metabolites of arachidonic acid on the growth of human mononuclear marrow cells and marrow stromal cell cultures. Med Inflamm 1998: 7: 31-33.

11. Triggiani M, Oriente A, de Crescenzo G, Rossi G, Marone G. Biochemical functions of a pool of arachidonic acid associated with triglycerides in human inflammatory cells. Int Arch Allergy Immunol 1995: 107: 261-263.
12. Chilton FH, Fonteh AN, Surette ME, Triggiani M, Winkler JD. Control of arachidonate levels within inflammatory cells. Biochim Biophys Acta 1996: 1299: 1-15.

13. MacDonald JIS, Sprecher H. Phospholipid fatty acid remodeling in mammalian cells. Biochim Biophys Acta 1991: 1084: 105-121.

14. Fonteh AN, Chilton FH. Mobilization of different arachidonate pools and their roles in the generation of leukotrienes and free arachidonic acid during immunologic activation of mast cells. J Immunol 1993: 150: $563-570$.

15. Konger RL, Malaviya R, Pentland AP. Growth regulation of primary human keratinocytes by prostaglandin $\mathrm{E}$ receptor $\mathrm{EP}_{2}$ and $\mathrm{EP}_{3}$ subtypes. Biochim Biophys Acta 1998: 1401: 221-234.

16. Dembinski A, Konturek SJ. Effects of E, F, and I series prostaglandins and analogues on growth of gastroduodenal mucosa and pancreas. Am J Physiol 1985: 248: G170-175.

\section{Received 4 January 1999; \\ accepted 3 February 1999}




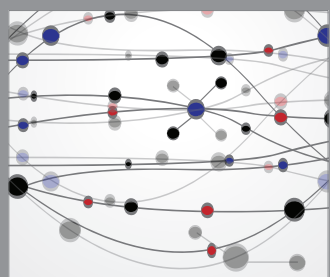

The Scientific World Journal
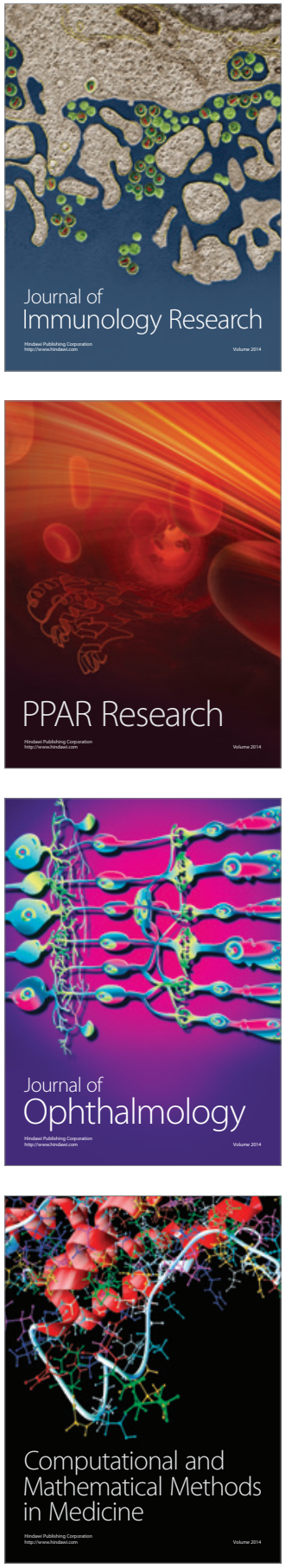

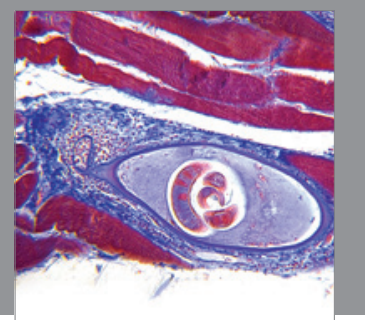

Gastroenterology

Research and Practice
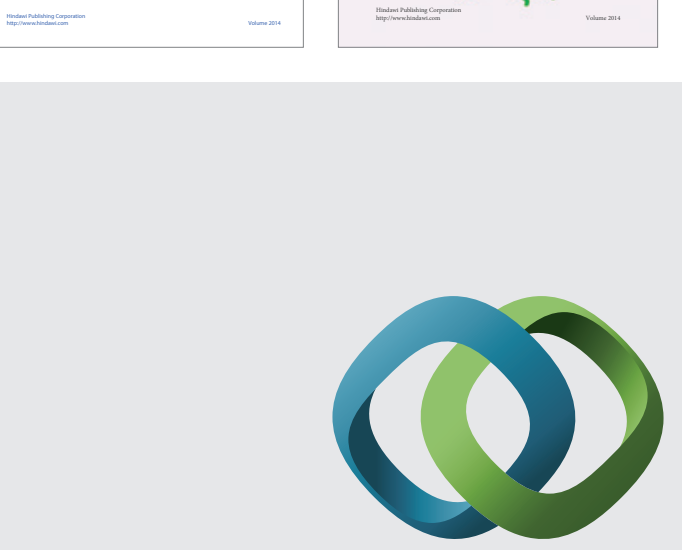

\section{Hindawi}

Submit your manuscripts at

http://www.hindawi.com
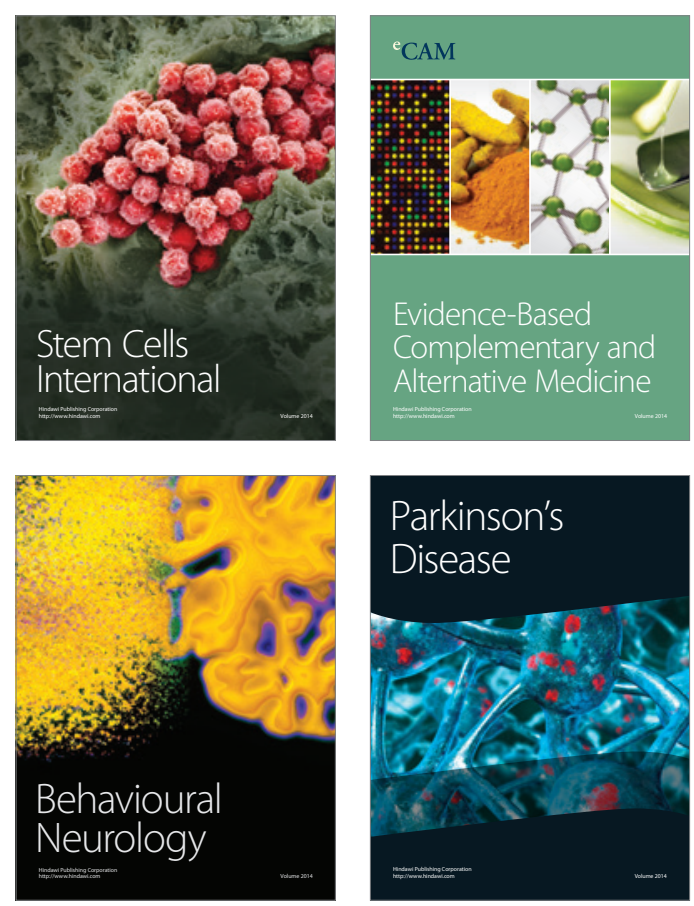

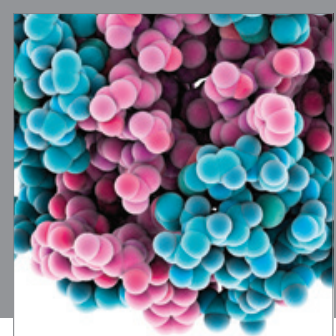

Journal of
Diabetes Research

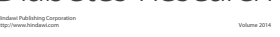

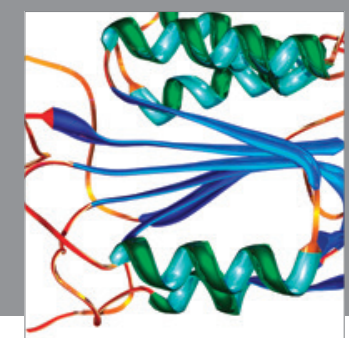

Disease Markers
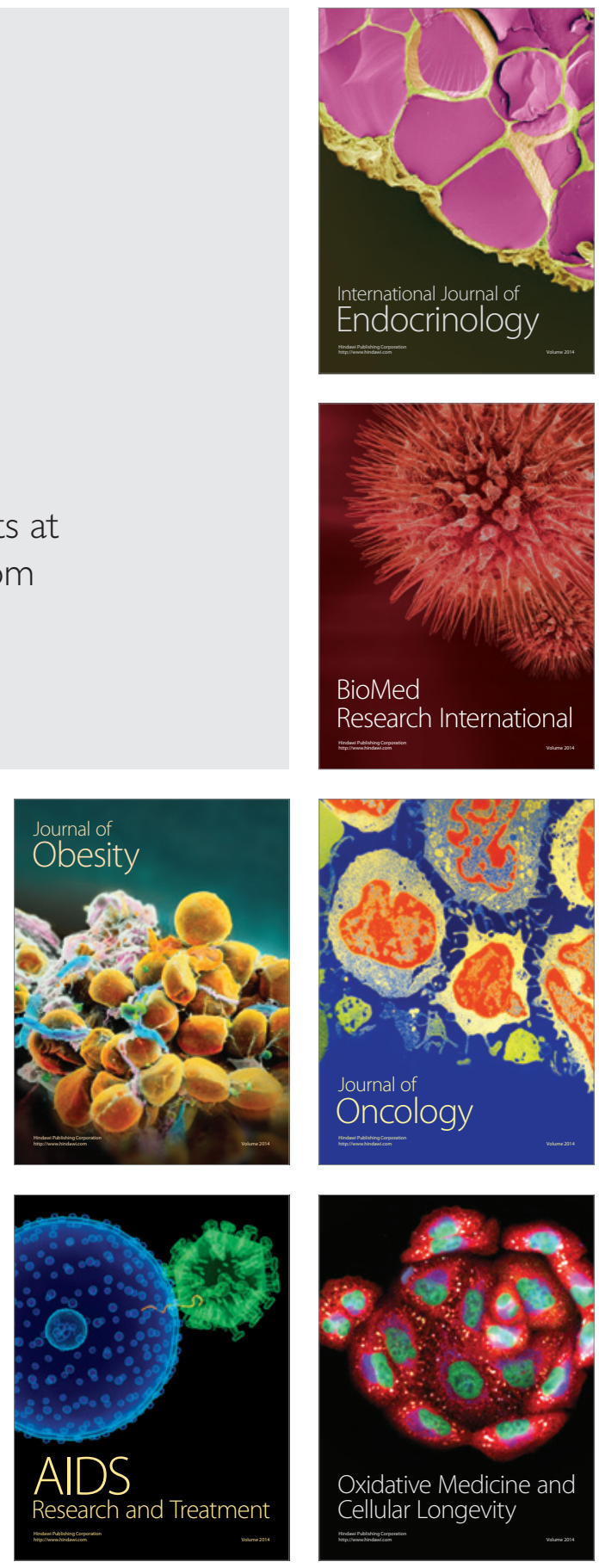